\title{
All News is Bad News: \\ Newspaper Coverage of Political Parties in Spain
}

\author{
Frank R. Baumgartner \\ University of North Carolina at Chapel Hill \\ Frankb@unc.edu \\ Laura Chaqués Bonafont \\ Universitat de Barcelona and Institut Barcelona d'Estudis Internacionals (IBEI) \\ laurachaques@ub.edu
}

\begin{abstract}
Spain has a highly partisan media system, with newspapers reaching self-selected partisan audiences and espousing explicitly partisan editorial preferences. Do the newspapers of the left and right differ in how they cover politics in ways that can be predicted by their partisan leanings? We review theories of issue-ownership, journalistic standards, and information scarcity and test hypotheses derived from each. We find that the parties converge substantially in virtually every aspect of their coverage. Few differences emerge when we look at what topics are covered or in the dynamics of which topics gain attention over time. However, we confirm important differences across the papers when they make explicit reference to individual political parties. Journalistic norms result in a surprising focus on the faults of one's enemies, however, rather than the virtues of one's allies. Our assessment is based on a comprehensive database of all front-page stories in El País and El Mundo, Spain's largest daily newspapers, from 1996 through 2011.
\end{abstract}

Keywords: political parties, political communication, agenda-setting, media and politics, Spain

Forthcoming, Political Communication, 2014

[Note: This version was accepted for publication in February 2014 but has not been copy-edited. Please refer to the published version for exact quotations and page numbers.] 


\section{News Coverage in a Partisan Environment}

Media coverage of politics is a fundamental matter for democracy. Democratic debate and civic discourse depend to a large extent on how the media gives access to policy actors to express their views and ideas about issues. Political communication scholars stress the privileged position of elites, especially governmental actors, in gaining access to the news (Bennett 1990, Iyengar 2011, Graber 2003). Journalists report about what political elites are doing or planning to do, often ignoring other policy actors who are deemed to be less newsworthy than "officials." Elite status is explained by formal rules governing the political system, but also informal rules more related to the seniority of a policy actor or tradition (Walgrave and van Aelst 2008). In this view media coverage is driven by the actions of political elites, real word events, and competition for readership, more than partisan logics or journalist preferences. In a different vein, media systems scholars stress the importance of political parallelism, journalistic professionalism, state regulation and media ownership in how newspapers cover politics (Seymour-Ure 1974, Blumler et al. 1992, Hallin and Mancini 2004). Media coverage reflects the preferences and partisan links between political parties and individual media outlets, which lead to important inequalities on how newspapers cover different parties. Some political elites would have more media coverage than others depending on the political orientations and ideological affinities of journalist (van Dalen and van Aelst 2013). It appears that cross-national studies emphasize differences based on ownership patterns and the degree of partisan connection in the media system. We contribute to these literatures by focusing on the two main daily newspapers in Spain, a country that has strong political parallelism and might be expected to show significant partisan differences in media coverage. In contrast to these expectations, we show that while differences are apparent, 
they are not as powerful as the similarities. These similarities are well explained by Bennett's indexing theory: Both parties give great deference to "official" sources.

However, when the two newspapers focus their attention on individual political parties, they show their biases. Rather than vaunt the proposals of their allied party or draw attention to the issues thought to be advantageous to them, however, we find that the bias comes in how they treat their rival. Each paper under-emphasizes the role of their allied party and over-plays the faults of the rival. Thus, the left-leaning El País provides much greater coverage of the Popular Party (PP), especially when government officials of the PP are involved in corruption scandals. In almost perfect parallel, the right-leaning El Mundo provides much less coverage of these scandals. But when a Socialist Party (PSOE) government is beset with similar corruption issues, the newspaper with most coverage is, naturally, the rival one. We therefore identify some partisan differences in coverage, but these are decidedly reactive and negative. With regards to parties, they downplay the actions of their allies and focus instead on heaping bad news on the rival. In all, Spain's two major national dailies have highly similar news agendas. But when they cover the activities of the political parties, all news is bad news.

\section{The Spanish Media System}

According to Hallin and Mancini (2004) Spain perfectly fits into the so-called polarized pluralist media system, characterized by a strong political parallelism, low circulation of newspapers, low professionalism, and high state intervention. In contrast to other countries (Seymour-Ure 1974, 2003), there is a strong link between media groups and political parties, reducing independent reporting about political campaigns (Sampedro et al. 2008), the people's knowledge about politics (Fraile 2010), how issues are framed (Baumgartner et al. 2008, Boydstun 2013, 
Arsenault and Castells 2008, Castells 2009), and more broadly media coverage of politics (Seymour-Ure 1974, Tresch 2009).

In Spain, to read a newspaper is to be associated with an ideological or partisan camp. In contrast to other countries (Seymour-Ure 1974, Gunther et al. 1999), this link between media groups and ideology is explained by readership patterns, more than ownership or/and the links and affiliations of journalists with a political party. Politicization of media outlets and the ideological fragmentation of readership have been in place from the transition to democracy to present (Gunther et al. 2000). During the late-1970s and 1980s this link was especially strong between El País and the Partido Socialista Obrero Español (PSOE), the ABC and conservative parties (first Alianza Popular and later Partido Popular), or/and La Vanguardia and Convergencia i Unió. The creation of El Mundo in 1989 reinforced the existing ideological fragmentation of readers across newspapers. Since its creation, El Mundo prioritized its task as a watchdog of Spanish politics, and the PSOE governments of Felipe González, and in less than five years it became the second most read newspaper, after El País (Chaqués-Bonafont and Baumgartner 2013). From the mid-1990s both El País (Grupo Prisa) and El Mundo (Unidad Editorial, $R C S$ ) have been the most read quality state-wide newspapers, followed by other conservative newspapers like $A B C$ (Vocento), or la Razón (Planeta), and territorially based newspapers like El Periodico de Catalunya (Grupo Zeta), La Vanguardia (Grupo Godó) o El Correo Vasco (Vocento).

In the case of La Vanguardia, and to a certain extent El Periódico de Catalunya (Grupo Zeta) ${ }^{1}$, this association between media and political parties is especially relevant in Catalonia. Most of La Vanguardia readers are voters of the center-right (Convergència i Unió - CIU), while most of the readers of El Periódico de Catalunya are voters of left Catalan parties, mainly the 
Partit dels Socialistes de Catalunya (PSC), Iniciativa per Catalunya Verds (ICV) and Esquerra Republicana de Catalunya (ERC). This illustrates another important feature of the Spanish media system: the fragmentation of readers across the territory ${ }^{2}$.

These general tendencies can be corroborated with survey evidence. According to the Centro de Investigaciones Sociológicas ${ }^{3}$, in 2009 more than $50 \%$ of the readers of El País identify themselves at an ideological position between 1 (far left) and 4 on a 10 point index from left to right. Compare this to just $6.8 \%$ of the readers of El Mundo (CIS, 2009). By contrast, more than $37 \%$ of the readers of $E l$ Mundo are above 6 in the left-right ideological scale, versus 9\% of the readers of El País. In terms of partisanship, about $30 \%$ of citizens that identify themselves as PSOE voters and $21 \%$ of Izquierda Unida (IU) voters are readers of El País, versus only $5 \%$ of PP voters. By contrast, about $23 \%$ of the readers of El Mundo identify themselves as PP voters, versus $4 \%$ and $2 \%$ of the voters of the PSOE and IU respectively.

These results are quite similar to those in the mid-1990s (Gunther et al. 1999). However, according to Gunther et al. (1999) in 1993 the average reader of El Mundo was placed at 4.6 on the left-right continuum and an important part of the far-left voters (mainly IU voters) were readers of El Mundo. This should be understood in the political context in the 1990s, characterized by the economic crisis and political scandals and corruption associated with the PSOE governments of Felipe González. These included scandals like the Antiterrorism Liberation Group (GAL), the Roldan case (General Director of the Guardia Civil, a paramilitary police force) or the Mariano Rubio case (Governor of the Bank of Spain until 1994; for more detailed information see Castells 2009, or Villoria 2007, Villoria and Jiménez 2012). As Castells (2009) highlights, since its creation in 1989, El Mundo was aimed at scrutinizing political elites, focusing on political scandals, and possible government law-breaking. El Mundo defined itself as 
the watchdog of the Spanish political system, and that captured the attention of some of the voters of the left that were critical and disenchanted with the governments of Felipe González (PSOE).

Globalization and increasing market competition did not limit political parallelism and ideological fragmentation of Spanish newspapers. In the new millennium, Spanish citizens read those newspapers that are closer to their political ideas, and newspapers respond to the ideological positions of their readers, reinforcing their perceptions about politics. None of the newspapers has abandoned its ideological position in order to capture a broader audience. On the contrary, market competition and globalization have reinforced a model of external pluralism in which newspapers are more and more controlled by political institutions ${ }^{4}$. The question is how external pluralism affects media coverage of politics. This is an important question in both normative and empirical terms. Existing theoretical analysis, from the indexing theory to the agenda setting approach, do not take into account media systems characteristics to explain media coverage of politics. Actually, the indexing approach was aimed to explain media coverage in the US. This is the best example of what Hallin and Mancini (2004) identify as a liberal media system, completely at odds with the functioning of the media system in Spain. On the other hand, agenda setting scholars provide a framework to better understand how and under which circumstances the mass-media and political elites influence each other, taking for granted the fact that media systems operate differently across countries, and that some features, like strong political parallelism, may have some impact on how newspapers perform their task as agenda setters, gate-keepers and watchdogs of the political system. The next section is aimed to provide a detailed discussion about these theoretical approaches, and define the hypothesis that lead the empirical analysis. 


\section{Literature and Expectations}

According to the indexing theory (Bennett 1990) journalists tend to focus on what the government is doing giving special place to "official" sources, discounting opinions that are marginal or not represented in the halls of government, and giving priority to the routine reporting of the actions of government officials. The media may reflect the debates among government officials and their rivals within the political establishment (Entman 2004, 4), but coverage is driven by the elites, not the independent judgments of the journalists. There are many reasons to expect some aspects of this indexing theory to hold: the media pays special attention to governmental actors because they are a legitimate source of information, fairly easy to access and obtain quotations (through press releases or written reports) and relatively inexpensive to cover (Castells 2009, Wolfsfeld and Sheafer 2006). This is especially convenient in a context of increasing business competition and reduction of market shares, in which most media companies have reduced the set of economic and human resources devoted to the direct coverage of news, and thus their capacity to independently provide reliable and contrasted information (Curran et al. 2011). Hence:

H1, Government indexing: Journalists report on the actions of "official" sources, and newspapers should therefore give enhanced coverage to government officials, no matter what the party in power.

This first hypothesis implies that the Indexing theory may apply not only in a media liberal system like the US, but all types of media systems. Governmental actors and political elites occupy a predominant position in any political system, either democratic or not. They are the main source of information and thus we expect journalist may follow what the government is doing with independence of the levels of media political parallelism, journalist professionalism, circulation of newspapers and state intervention. The same applies for a rarely discussed element 
of Bennett's theory: its "mainstream government debate" bias. He writes that the media "tend to index the range of voices and viewpoints in both news and editorials according to the range of views expressed in mainstream government debate about a given topic" (Bennett 1990, 106). Most of time, the media abdicates from the normative mandate of giving voice to the people providing independent and plural information, and only occasionally take into account the points of view different from the mainstream official view of the government and the most prominent political parties. He suggests that journalists cover "official" beats and therefore index their coverage to the actions of government officials. They also look for response by other mainstream political actors outside of government (Kepplinger et al. 1991). They do not, however, look to the fringes of the political system for viewpoints that may be loud and clear to those who look but which fall outside of the major political parties.

In Spain, what this suggests is an extensive focus by the mainstream media on the two major political parties, well beyond their importance in the polls. Since 1996, the PP has received between 38 and 45 percent of the popular vote in successive legislative elections, and the PSOE 29 to 44; together they have gotten between 84 and 92 percent of the seats. This means both PP and PSOE almost monopolize the legislative process and control activities at the parliamentarian arena — from 1982 to 2011 only $5 \%$ of the parliamentary bills introduced by political parties other than the PP or/and the PSOE were passed and about $85 \%$ of the oral questions in plenary meetings are introduced by these two parties. By the same token, both the PP and PSOE monopolize most of the decisions related to institutional appointments and representation, such as designation of the members of the Constitutional Court. All of this confers on the two main parties an elite status, and news value much higher than any other actor in the political system. 
Other parties, especially the far left (IU) and regional ones powerful in Catalonia (CIU and ERC), in the Basque country (mainly Partido Nacionalista Vasco PNV), Galicia (Bloque Nacionalista Galego BNG), or the Canary Islands (Coalición Canaria), may be expected to receive less than their proportionate share of media coverage. This is particularly the case when the party in government has the absolute majority of seats (e.g., during the PP government of José Maria Aznar from 2000 to 2004). By contrast, access of regional political parties to the front pages of the most read Spanish newspapers should be larger when they play the role of pivot in government formation. This is the case of CIU during the first government of José M. Aznar from 1996 to 2000, or ERC, IU-ICV and BNG during the minority governments of José Luis Rodríguez Zapatero (2004-2011). In this political context, regional parties gain "news value" and consequently have a higher capacity to get into the news. In short, following from Bennett's indexing theory,

H2: Reinforcement of the partisan elite: both newspapers will be highly selective in their attention to political parties, focusing largely on the two predominant parties. Access to the media by smaller and regional parties is lower, and varies across time depending on their "news value."

Elite status and news value are two of the factors explaining media access. Other factors, like the level of conflict related to the message, the novelty of a story, the type of issue or the possibilities of dramatization are also important to explain access to the news. Walgrave and van Aelts (2006) suggest dependence of the media towards governmental actors is especially important for issues like foreign affairs and defense for two main reasons: first, these are obtrusive issues for which most journalists may not have direct experience, or the resources to gather information directly. Second, these are issues for which the executive has institutional 
ownership - that is, formal rules guarantee a predominant role of the executive in front of other policy actor in the policy-making process (Walgrave et al. 2008, Seymour-Ure 2003).

As in many other majoritarian democracies, in Spain the Prime Minister occupies a leading role in the policy making process, and this is especially the case for foreign and defense policy and for questions relating to the European Union; in these areas the Prime Minister's office (Presidente del Gobierno) almost monopolizes the agenda-setting process. The decision to send military troops corresponds exclusively to the Prime Minister, which also concentrates all the political responsibility and electoral costs associated with that decision. The same occurs in relation to EU matters. It is the Prime Minister who leads the process of European integration, participates in EU meetings and negotiates vis-à-vis other heads of government important aspects of the agenda that will be later implemented at the national level. Once the decision is made at the EU level, it is quite difficult, costly and time consuming to amend EU decisions in the parliamentary arena. In contrast to other countries, the Spanish government is not obliged to explain its negotiation strategies at the EU level, or the financial implications generated by a new agreement. MPs have to rely on raw EU-related documents to get most of the information about what is going on at the European arena, and have no capacity to impose parliamentary positions on the government (e.g., Raunio 2005). Accordingly, most stories about the EU, international affairs, or defense will inform about the activities and policy positions of the Prime Minister, and thus we expect:

$\underline{\text { H3, Government information advantage: For foreign policy, defense, and EU-related }}$ issues, governmental information advantage is so great that both newspapers will offer greater coverage to government officials in these areas compared to others, no matter the party in power. 
Variations in media coverage of political parties also depends on the degree of controversy or disagreement about various issues. It is not rewarding in political terms to pay attention to issues about which everybody agrees (Green-Pedersen and Stubbager 2011, Thesen 2013). The general agreement about the benefits of the EU that traditionally has characterized Spanish politics prevents political parties from seeking media attention on EU matters. By contrast, political parties will seek media attention when they have an alternative and strong claim, different from the governmental position on a particular issue (Entman 2004). This is the case of the Iraq conflict at the beginning of the new century. The entry into the war of Iraq was one of the most controversial decisions taken by the majority government of José Maria Aznar, generating an intense and politicized debate in and out of the parliamentary arena. Political parties and other policy actors, mainly social movements, gained some media access reflecting the opposition to the military intervention in Iraq by most of the Spanish population.

In short, in a context of agenda scarcity political parties will concentrate their efforts to gain access in relation to issues that either have a strong capacity to attack the party in government, or reinforce issue-ownership (Thesen 2012, Green-Pedersen 2006; Budge and Hofferbert 1990; Klingemann et al. 1994). As rational actors they will devote their attention strategically across issues depending on whether the electorate identifies them as capable to give an optimal solution, presenting an alternative policy position that challenges governmental arguments and ideas. This means political parties, especially those in opposition, have some capacity to select the issues they discuss, picking and choosing the issues on which they seek to make media-ready statements and generally avoiding the unpopular ones.

In contrast, the incumbent party has to inform the public about what is doing or planning to do independently of the level of saliency of the issues at hand. Every Friday, after the weekly 
meeting of the Council of ministers, the executive's speaker informs the press about the decisions taken by the executive, which may include salient issues, but also regulatory changes that generate no political debate. Newspapers will report about both, giving more priority to highly politicized issues, of course. For salient issues, like same sex marriage, or immigration, newspapers inform about the policy position of both government and opposition parties, while in the case of non-salient issues - like a new plan to prevent car accidents - newspapers will only report about what the government is doing, basically because there are no further reactions by other actors. Accordingly,

H4: Government agenda fragmentation: Media coverage of government activities is more fragmented across issues than media coverage of political parties.

Newspapers contribute to this issue-selection process of their allied political parties. In doing so, newspapers will follow the ongoing political debate, highlighting the failures and inconsistencies of the opposing party in relation to highly politicized issues, focusing on what is wrong, and always giving the bad news (Baumgartner et al. 2011). This does not mean newspapers are able simply to focus on the issues they prefer. Newspapers focus on bad news reflecting one of its basic functions in a democracy_holding current government elites accountable, and thus, informing about negative developments in economic, political and social problems (Soroka 2006). Most of the time, as the indexing theory would suggest, newspapers inform about the government-opposition game, giving access to both opposition parties (who highlight what is wrong in politics) and governmental actors (who highlight good news about politics but also are forced to react in front of bad news; Thesen 2013).

As a result of these dynamics, media attention tends to be highly concentrated on the same issues across media outlets and time (Baumgartner and Jones 2005, Boydstun 2013). Based 
on a large-scale assessment of the content of all stories appearing on the front pages from 1996 to 2009, Chaqués Bonafont and Baumgartner 2013 demonstrate that El País and El Mundo cover the same topic areas, focusing attention equally on certain topics to the detriment of others, with substantial "friction" in how they shift attention from topic to topic without much variation across time. But occasionally, events give the opportunity to portray a sitting government or/and political adversary in an unflattering light. This is specially the case of political scandals involving members of the executive or/and political parties. For these issues we expect that the newspaper of the rival ideological camp will give greater attention to political scandals compared to the ideologically allied media outlet. If this argument is correct we should expect:

H5, Faults of the partisan opponent: Newspapers will seek to highlight the flaws of their partisan rivals by focusing on embarrassing stories relating to their rivals when they are in government, such as corruption issues.

Note that our last hypothesis refers only to bad news and suggests that newspapers may systematically contribute to the public perception that politics is inherently corrupt. If the allied paper refuses to cover the topic when an allegation is laid down, but the opposition paper enthusiastically attempts to keep the topic on the front pages, the net result may be more coverage of bad news than good. If generalized, this may be a reason for increased levels of public distrust of government.

Finally, we also expect access to the media follows a different logic during routine periods as compared to during electoral campaigns (Walgrave and Van Aelts 2006). Before elections, political parties become the protagonist of the political debate, searching access to the media either to defend their political program, to foster the debate about some issues, or to criticize their opponents. They gain "news value" and become an important source of 
information, supplying journalist with an overwhelming amount of "easy-to-get" news in different formats, from public events and ceremonies ending with a photo, to reports and briefings about issues, provocative statements, or/and press releases.

This does not necessary mean that during election time media coverage of politics will be fragmented across political parties. On the contrary, authors like Sampedro (2004), Sampedro and Seoane Pérez (2008), González (2008), Semetko and Canel (2010) stress the Spanish media system is evolving from polarized pluralism to antagonistic bipolarization in which the two main state wide political parties dominate the political debate, and this is specially the case during political campaigns. In this view, changing market conditions and increasing concentration of power in a few media groups have reinforced the politicization of the Spanish media to the extent that other political forces different from the PP and PSOE are left to a marginal position in media coverage. As a result, we expect:

H6, Election Effect: For political parties, access to the front pages increases during electoral campaigns, while the opposite occurs in the case of the executive.

H7, Dominant Party Effect: The PSOE and the PP monopolize coverage during elections as compared to other parties.

\section{Data}

To analyze who gets into the news, and who gets formally identified in a policy debate we take into account the content of all the front-page stories of El Mundo and El País, for the period 1996 to 2011. To do that we rely on the databases of the Spanish policy agendas project (www.ub.edu/spanishpolicyagendas) developed following the methodology of the Comparative

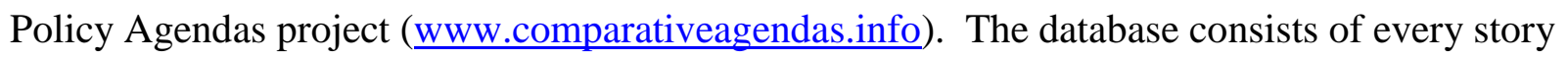
on the front page of the two papers from January 1, 1996 through December 31, 2011: 50,775 
stories from El País and 56,540 stories for El Mundo. For each story we have recorded the date of publication, title, and the topic of the story which is classified according to 23 major topics and 247 subtopics (see table 1 in the annex). Each story has been coded by two different coders with a reliability of 93.25 percent at the topic level and 90.35 percent at the subtopic level.

In order to explain who has access, these databases provide information about the actors involved in each story. We gathered information about whether the story mentions members of the executive (Prime Minister, Ministries, and/or the Head of the State), members of the Spanish parliament; political parties (with and without representation in Parliament); regional political elites (the head of the regional government) regional parliaments; and interest organizations (interest groups, social movements). From here, we can measure media presence (whether a given type of political actor appears in the media) and media prominence (the number of times a political actor appears; see Tresch 2009). To measure media prominence of governmental actors we take into account any mention to what the executive is doing or planning to do. This category includes all stories that directly refer to the Presidente del Gobierno (mentions to José Maria Aznar from 1996 to 2004, or José Luis Rodríguez Zapatero from 2004 to 2011), to the executive as a whole (like the Council of Ministers) or a Minister. All these political actors were coded separately, but for the analysis presented here, we count the prominence of "government actors" as the number of stories in which any of these actors was mentioned.

In the case of political parties, media coverage is measured taking into account all mentions of a political party. Each story can refer to more than one political party or/and governmental actor. We have also created a dummy variable to capture political actors" "elite status." When small and regional political parties give stable support to the incumbent government we coded as 1, and 0 otherwise. During the PP government of José Maria Aznar 
(1996-2004), CIU, and CC always gave support to the incumbent party, while the PNV did so only from 1996 to 2000. In the case of the PSOE governments of José Luis Rodríguez Zapatero, the support came from ERC and CC for the whole period (2004-2011). The far left (IU) only gave occasional support to the socialist government and this was especially the case from 2004 to 2008. We excluded from the analysis all stories that only refer to policy actors from abroad.

We also distinguish between election and routine times. We considered election times to start two months previous to the General Elections. Finally, in order to control for the impact of the economic crisis on media coverage of politics we use the indicator "Current Economic Situation" developed by the Centro de Investigaciones Sociológicas (www.cis.es). This indicator is developed from the one of the questions of the monthly barometers (except August, when the survey is not conducted): "Referring now to the general economic situation in Spain, how would you rate it: very good, good, so-so, bad or very bad?" This indicator is especially useful to assess the impact of the economic crisis, mainly because it directly provides information about the perceptions of citizens about the economic situation in Spain, which at the same time are highly correlated with other economic indicators like unemployment for example, for which there is not monthly data available. It is important to note that while we have coded data at the level of the individual story, with over 100,000 stories coded, the analysis we conduct in this paper is about trends over time. To do this, we have aggregated all our data to the monthly level. Thus, our focus is on the percentage of all front-page stories per month in which each type of actor appears. (We use percentages rather than counts because the total number of stories per month varies.)

\section{Results}

Table 1 summarizes media coverage of governmental actors and political parties from 1996 to 2011. Overall, almost one third of the stories in the front pages of El País and El Mundo directly 
mention a member of the Spanish government or/and a political party. Governmental actors (mentions to the Presidente del Gobierno, individual Ministries or the Executive as a whole) and the two large state-wide political parties capture most of media coverage in both newspapers - to the relative exclusion of smaller and regional parties. Less than one percent of the stories of $E l$ País and El Mundo directly mention the far left, Izquierda Unida (IU), and regional political parties account for less than two percent of the stories. This is especially the case when the PSOE is governing from 2004-2011. The Basque and Catalan parties are newsworthy mostly when "relevant" issues are discussed: regional autonomy issues, or Basque-related terrorism issues, and when they are pivotal in government formation. The far left parties, unrelated to regional concerns, receive significantly less coverage proportionately than their results in popular elections would suggest they might. Besides, most stories that refer to the far-left also mention another political party, especially the PSOE. Clearly, there is a bias toward the establishment.

Table 1 about here

The Spanish executive enjoys a significant advantage in coverage compared to any other actor suggesting that Bennett's (1991) indexing theory is more prominent in explaining these trends than any effort by ideologically driven editors to help the party to which they feel greater warmth. Thus, we confirm H1. Also, Table 1 suggests both newspapers are highly selective in their attention to political parties, focusing largely on the two predominant parties, and that they pay more attention to their ideological opponents, than their allies, no matter which party is governing. About $8.8 \%$ of the stories of El País refer to the conservative Partido Popular (PP), and only $6 \%$ to the PSOE, while $11 \%$ of the stories of El Mundo refer to the PSOE versus $8 \%$ to the PP. This is the case for the whole period with some minor exceptions, like El País paying 
more attention to the PSOE from 2010 during the economic recession, or El Mundo paying relative more attention to the PP right after the winning of elections in 1996.

Further, as stated in hypothesis 2, access to the media varies across time depending on the "news value" of political actors. We expect media coverage of political parties increase when they are governing (in the case of the PP and PSOE) or giving support to the government, which relates to small and regional parties like CIU, PNV, ERC, BNG or IU. Also, hypothesis 7 states that access of small and regional parties may decrease during election time compared to statewide political parties. To test these hypothesis we defined an OLS regression model in which the dependent variable is the percentage of stories in a given month mentioning a particular political party, and the independent variables are (1) support for the government ( 1 when the party is governing or giving support to the governing party, and 0 otherwise); (2) elections (1 for the two months prior elections and 0 otherwise); and (3) economic crisis (defined as the percentage of citizens that consider the economic situation in Spain is good, from the monthly survey data described earlier). This economic crisis variable allows us to assess whether the economic crisis alters somehow the predicted pattern of polarization and concentration of attention in the Spanish media. The definition of these variables is summarized in Table 2 .

Table 2 about here

Table 3 presents the results. Overall, the explanatory capacity of the model is high and significant, and this is especially the case for El Mundo. The table contains a lot of information, as it has separate models for each newspaper, and each political party. Looking first at the two major parties, it is clear that attention increases dramatically to them during elections (where their share of attention in front-page stories increases by 3 to 7 percent), and when they are in the government. During good economic times, defined by survey evidence, attention to these parties 
declines; their actions are more newsworthy during periods of economic crisis. For the smaller parties, results are nuanced: Giving support to the government typically makes these parties more newsworthy, though there are null results for IU and PNV on this matter. Results indicate IU loses media access particularly when it is giving support to the PSOE government of Rodriguez Zapatero. This, however, coincides with a dramatic decrease of the number of seats the party controls in the Spanish Parliament (21 in 1996; just two in 2011). Support to the governing party is especially important to explain attention to ERC, which increases its news value and elite status after 2004 not only because it gives stable support to the Spanish government, but also because it increases the number of seats in the Spanish Parliament from two to eight, and it is governing in Catalonia in coalition with the PSC and ICV. The same occurs in the case of CIU, which from 1996 to 2004 gives support to the governments of José Maria Aznar, and until 2003 is governing under minority in Catalonia. In the case of PNV results are only significant in the case of $E l M u n d o$, which may be related to the introduction of the Plan Ibarreche — a reform of the Basque statute — in 2001.

Results from Table 3 suggest that media coverage is not only linked to changes in the parties' news value in terms of whether they give support to the incumbent party, but also their status as legitimate and important actors in the political debate about issues related to political decentralization. Thus, we can see increases in attention to the regional parties during periods surrounding such events as the regional fiscal reform of late nineties promoted by CIU during the minority government of José Maria Aznar, the introduction of the Plan Ibarreche by the PNV in the early 2000, or the reform of the statute of Catalonia (2004-2008) led by the Catalan coalition government (PSC, ERC and ICV). Regional political parties are a legitimized voice in this debate, increasing their elite status and newsworthiness. 
Second, coefficients about the importance of election periods are also positive and significant for the case of the PSOE, PP and IU, which indicate that stories mentioning these political parties increase during elections in both newspapers. In contrast, in the case of regional parties, coefficients are not significant for either of the two newspapers. Access to the front pages by the PNV, ERC, or CIU is larger during routine periods than election times in the case of El País, and to a lesser extent in El Mundo. In both newspapers, regional political parties get access to the front pages in relation to specific issues, mainly terrorism and voting rights for the case of the Basques, and political decentralization for the case of Catalans. But during the political campaign they are completely overshadowed by state-wide parties.

This is particularly the case from 2004 general elections. As Figure 1 illustrates, there is an increasing bipolarization of the electoral campaigns between the PP and PSOE, which corroborates existing analysis about media and elections in Spain (Sampedro 2008, Castells 2009). El País and El Mundo increasingly concentrate their attention on what their enemies are doing, saying or/and planning to do, contributing to the polarization and negative coverage of politics. One of the main consequences of this polarization is the decrease of the privileged position of governmental actors during electoral campaigns in relation to political parties. As Figure 2 illustrates, attention to governmental actors is more relevant during routine periods, especially for the case of El País, while the opposite occurs for the case of the PP and PSOE.

Figure 1 and 2 about here

Finally, the economic situation is an important factor to explain levels of attention to the main and regional parties. The worse the perception of citizens about economic conditions, the more attention is paid to the PP and PSOE. Attention to the PNV and ERC is positively related to the state of the economy, on the other hand. This suggests that during periods of economic 
crisis, attention shifts to the main parties, reinforcing the polarization of the political debate between the two main political forces. Election periods are also clearly times when the newspapers clearly focus their front-page attention on the main parties at the expense of those either ideologically at the margins, or focused on regional causes.

Summing up, these results corroborate existing analysis about who gets in the news. Parties dominate the electoral period, of course, but official sources are predominant during other periods. Thus we can also confirm hypothesis 6 and 7: Parties are the focus during elections, and that focus is highly beneficial to state-wide political parties the dominant party actors. We also find support for hypothesis 2: News value, measured here as support to the government, is an important factor to explain media coverage of regional parties (though not the far left). From here further analysis should test whether these differences in access to the front-pages between state-wide and regional parties, and between routine and election times are also present in other sections of El País and El Mundo.

Hypothesis 3 relates to the government's information advantage. Figure 3 shows the percentage differences of all stories mentioning governmental actors and political parties by policy topic, for both papers. Positive coverage means attention to actors within the federal executive branch (e.g., the Prime Minister, a minister, or an agency of government at the national level) is larger than attention to political parties as a whole. As Figure 3 illustrates, government advantage is substantial for all issues except for one: Government operations issues, which include elections, political parties as organizations, political scandals, regulation of electoral campaigns, and relations between the executive and legislative branch.

Figure 3 about here 
Political parties also appear more than the government with regards to terrorism and voting rights. Both newspapers give substantial access to Basque in relation to ETA (Euskadi Ta Askatasuna) terrorism, and also in relation to the so-called Ley de Partidos. The parliamentary discussion of this law was one of the most controversial and politicized issues of Spanish politics of early 2000, generating and intense confrontation between Basque political parties on one side and state-wide parties on the other. Once the law passed in 2002, the Supreme Court outlawed several Basque political parties_-Herri Batasuna and Batasuna, Euskal Herritarrok, Basque Nationalist Action and the Communist Party of the Basque Lands and others-claiming they were giving support to the terrorist group ETA and never rejected violence as a means of politics. ${ }^{5}$ As Figure 2 shows, media coverage of Basque parties is especially large from 2000 to 2004, and this is related to this Ley de Partidos, and as stated above, to the discussion of the 2001-2003 Plan Ibarreche concerning the Basque country in the Spanish Parliament.

For all other issues, governmental actors always get more coverage and this is especially the case of foreign affairs, the EU and defense. In the case of El País, mentions to governmental actors are $66 \%$ higher than the mentions to political parties in relation to foreign affairs, and $45 \%$ higher in the case of war. Thus, we confirm the information advantage hypothesis (H3), but also find that the hypothesis is incomplete. Government advantage is not limited to foreign and defense issues; but includes all issues with the exception of regulation of political campaigns, internal organization of parties or specific issues like terrorism or voting rights.

Our fourth hypothesis relates to issue fragmentation. Our argument holds that media coverage of government activities is more fragmented across issues than media coverage of political parties mainly because the capacity of parties to select which issues to get involved with is larger than that of the government. That is, while parties choose the issues on which they want 
to be involved, the government must be involved in a wide range of issues, whether it prefers to be associated with them or not; therefore its coverage should be more fragmented across issuedomains. To measure fragmentation we computed Shannon's H Information Entropy formula. ${ }^{6}$ It is measured by multiplying the proportion of attention a policy actor receives for each issue, by the log of that proportion, then taking the negative sum of those products. The higher the score, the more fragmented the agenda of a political actor. Figure 4 shows the governmental agenda is always more fragmented across issues than the agenda of the PSOE and the PP without much variation across time. Actually, in both newspapers, about $60 \%$ of the stories referring to political parties are related to political campaigns, scandals of corruption and the internal organization of parties. This is, most of the time, mentions to the PSOE and PP are not linked with the discussion of specific issues, and do not reflect policy positions, but other concerns more related with electoral competition and corruption. It is interesting that in both newspapers, attention to governmental actors is increasingly concentrated on a few issues. From 2010, mentions to governmental actors are more and more related to the evolution of the economy, and the economic crisis which clearly reflects the impact of economic recession on politics.

Figure 4 about here

Our next hypothesis relates to partisan targeting and bad news. Here we go further in looking not only at which parties are discussed in which newspapers, but we focus specifically on the topic of political corruption scandals. When corruption stories occur, who covers them? This allows an additional test of H5, on targeting one's rival as opposed to one's ally. In the context of a corruption allegation, the best media defense is often simply to ignore the issue, but the best media strategy of attack is to generate higher and higher salience to the issue. Therefore, for this particular type of media coverage, we confirm H5 very strongly. Figure 5 makes clear 
that if one seeks news about the corruption scandal of a given official, it is best to read the paper ideologically hostile to them.

Figure 5 about here

Figures 6 and 7 delve more deeply in these comparisons by looking at a number of distinct policy issues: terrorism, political rights, elections, regions (political decentralization), corruption, government justice, civil rights, and the economy. First for El País and then for El Mundo, the figure compares four time periods, showing the relative attention to the PP minus that of the PSOE. Positive numbers therefore represent a higher percentage of total attention to the PSOE as compared to the PP. To confirm H6, therefore, we would expect El País to show positive numbers while El Mundo would have negative numbers. And indeed this is what we see, no matter which party is in power.

Figures 6 and 7 about here

At first glance, these figures show newspapers are not paying special attention to their ideological allies. Neither El País nor El Mundo is reinforcing patterns of ownership of certain issues by the two parties. On the contrary, these figures clearly illustrate that both $E l$ País and $E l$ Mundo pay more attention to their enemies than their allies for all issues and across both periods of government and opposition, with some minor exceptions, like economic issues. Attention is always larger for the case of the PSOE in both newspapers, but this is explained by the economic crisis starting in 2007 under the government of JL Rodríguez Zapatero.

Figures 6 and 7 also illustrate attention to the rival party increases when that party is governing. When the PP is governing (1996-2004), El Mundo pays a similar amount of attention to both political parties for most issues with the exception of corruption and governmental issues, while the opposite occurs during the governments of José Luis Rodríguez Zapatero (2004-2001). 
Once the socialists gain office, El Mundo devotes an increasing share of attention to the PSOE, attention that in some cases more than doubles the attention to any other policy actor. This trend is not so clear for the case of El País. Attention to the PP in El País increases when Jose Maria Aznar is governing, but differences are not so intense. These results clearly illustrate both newspapers are paying a disproportionate attention to their enemies, and this is the case for all issues independently of which political party is considered as better able to deal with a particular issue. These tendencies are reinforced with the rival party is in power.

\section{Discussion}

We have compared media coverage across more than 15 years of Spanish politics. Our results corroborate Bennett's indexing theory. The two leading national newspapers clearly exhibit a great deal of deference to the sitting Prime Minister, especially in those issue-domains where the national executive has an information advantage: foreign affairs, EU and defense matters. But governmental actors do not dominate media coverage alone; rival parties are also discussed, though this attention focuses on the mainstream, not the fringe or smaller parties. Both newspapers reinforce the already dominant position of the PSOE and the PP in the Spanish political system, relegating to a marginal position to small and regional political parties. We also demonstrate access by regional parties varies across time depending on their news value and the level of politicization of some issues. CIU, ERC and the PNV get into the front pages when they are pivotal in government formation, when they are governing in their territories, and for the debate of specific issues, especially those related to political decentralization and in the case of the Basques, terrorism and voting rights. ${ }^{7}$

Our results also indicate attention to political parties increases during election time, but only for state-wide parties. During electoral campaigns, the PSOE, PP and the far left get more 
media coverage than during routine times, and there is a clear trend towards increasing polarization of the electoral campaign around the two main political parties. This gives support to existing analysis about the media and electoral campaigns in Spain, and also indicates the level of politicization of the Spanish media outlets (Sampedro 2004, Hallin and Mancini 2004). Finally, we show that political parallelism is an important element in explaining how newspapers cover politics. Journalistic norms, news value, and focusing events cannot explain why for some issues, like political scandals, both newspapers present such a different media coverage. Our results clearly indicate that where the most important ideological differences emerge, it is in the area of covering corruption scandals. Where a government official of the rival ideological camp is in the spotlight, attention burns brightly. Where an allied official is targeted, journalists decide they can leave this coverage to their rivals. So, we can confirm that partisanship generally plays a surprisingly small role in determining what topics are newsworthy in Spain's leading newspapers, but that when attention focuses on the political parties themselves, all news is bad news. Of course, we measure newspaper coverage only according to the topic considered, and it is likely that if one looked more deeply in to the journalistic angles and detailed perspectives offered within each story, greater partisan difference would be apparent from what we have discovered. Still, we have demonstrated that there need be no concern that the main Spanish newspapers are covering the political world so differently, based on their partisan preferences, that they discuss only those topics that are convenient or ideologically acceptable, which is an important prerequisite to democratic discourse and civic engagement. At the same time, we have shown important partisan difference with respect to coverage of ideologically distant political actors as compared to allies. Further research on these important topics will certain fill in some 
of the gaps remaining, and we hope that this analysis will serve as an important first step in that endeavor.

\section{REFERENCES}

Arsenault, Amelia A. and Manuel Castells. 2008. The Structure and Dynamics of Global MultiMedia Business Networks. International Journal of Communication 2, 707-748.

Baumgartner, Frank, and Bryan D. Jones (1993). Agendas and Instability in American Politics. Chicago: University of Chicago Press.

Bennett, Lance W. 1990. Toward a Theory of Press-State Relations in the United States. Journal of Communication 40 (2):103-25.

Bennett, W. L. 2004. Global Media and Politics: Transnational Communication Regimes and Civic Cultures. Annual Review of Political Science 7: 125-148

Berges, Laura. 2010. Poder politico, económico y Comunicativo en la sociedad neoliberal. Revista Latina de Comunicaión Social 65: 244-254.

Blumler, Jay G, Jack M. McLeod, Karl Erik Rosengren. 1992. Comparatively Speaking: Communication and Culture Across Space and Time, London: SAGE Series in Communication Research.

Boydstun, Amber. 2013. Making the News. Politics, the Media and Agenda Setting, Chicago: University of Chicago Press.

Budge, Ian, and Richard I. Hofferbert. 1990. Mandates and Policy Outputs: U.S. Party Platforms and Federal Expenditures. American Political Science Review 84: 111-32.

Bustamante, Enrique (ed.) 2002. Comunicación y cultura en la era digital: industrias, mercados y diversidad en España. Barcelona: Gedisa. 
Castells, M. 2009. Communication Power. Oxford: Oxford University Press.

Chaqués Bonafont, Laura, and Frank R. Baumgartner. 2013. Newspaper Attention and Policy Activities in Spain. Journal of Public Policy 13, 1: 1-24.

Curran, James, Shanto Iyengar, Anker Brink Lund and Inka Salovaara-Moring. 2009. Media System, Public Knowledge and Democracy: A Comparative Study. European Journal of Communication 24, 1: 5-26.

De Mateo, R., Bergés L. y Garnatxe, A. 2010. Crisis, ¿qué Crisis? Los medios de comunicación: empresas y periodismo en tiempos de crisis, en Francisco Campos (coord.) El cambio mediático. Sevilla/Zamora: Comunicación Social, pp.75-106.

Entman, Robert. 2004. Projections of Power: Framing News, Public Opinion, and U.S. Foreign Policy. Chicago: Chicago University Press

Fraile, Marta.2010.Widening or Reducing the Knowledge Gap? Testing the Media Effects on Political Knowledge in Spain (2004-2006). The International Journal of Press/Politics 16, 2: 163-184.

Gandy, Oscar H. Jr. 1982. Beyond Agenda Setting: Information Subsidies and Public Policy. Norwood, NJ: Ablex Publishers.

González, Juan Jesús. 2008. "Los medios en la democracia avanzada. ¿Hacia una democracia de audiencia?'” In Tres décadas de cambio social en España, eds. Juan Jesús González and Miguel Requena. Madrid: Alianza Editorial (2th ed)

Graber, Doris 2003. The Power of Communication. Managing Information in Public Organizations. Washington: CQ Press. 
Green Pedersen, C. and R. Stubager. 2010. The Political Conditionality of Mass Media Influence: When Do Parties Follow Mass Media Attention? British Journal of Political Science 40: 633-677.

Gunther, R. Montero, J.R. Wert, J.I. 1999. The Media and Politics in Spain: from Dictatorship to Democracy. Institut de Ciències Polítiques i Socials WP 176.

Gunther, Richard and Anthony Mughan. 2000. Democracy and the Media. Cambridge: Cambridge University Press

Hallin, D. C. Mancini. P. 2004. Comparing Media Systems. Three Models of Media and Politics. New York: Cambridge University Press.

Hamilton, James T. 2004. All the News That's Fit to Sell: How the Market Transforms Information into News. Princeton, NJ: Princeton University Press.

Iyengar, Shanto, and Jennifer A. McGrady. 2007. Media Politics: A Citizen's Guide. New York, NY: W.W. Norton \& Company.

Iyengar, Shanto. 1991. Is Anyone Responsible? How Television Frames Political Issues. Chicago: University of Chicago Press.

Jones, Bryan D., and Frank R. Baumgartner 2005. The Politics of Attention. Chicago: Chicago University Press.

Jones, E. Daniel. 2007. Grupos mediáticos y culturales en España. Zer 22: 183-214

Kempen, Hetty van. 2007. Media-Party Parallelism and its Effects: A Cross-National Comparative Study. Political Communication 24: 303-320

Kepplinger, Hans M., HB. Brosius and JF Staab.1991.Instrumental Actualization: A Theory of Mediated Conflicts. European Journal of Communication 6: 263-290 
Kepplinger, Hans M. 2002. Mediatization of Politics: Theory and Data. Journal of Communication 52, 4: 972-86.

Klingemann, Hans-dieter, Richard Hofferbert, Ian Budge. 1994. Parties, Policies, and Democracy. London: Westview Press.

Llorens, Carles. 2010. Spain's Media Concentration Policy: A Patchwork Crucial to the Understanding of the Spanish Media System, International Journal of Communication 4: 844-864.

McChesney, Robert. 2003. Theses on Media deregulation. Media, Culture and Society, 25:125133

Norris, Pippa. 2000. A Virtuous Circle. Cambridge: Cambridge University Press.

Palau, Anna and Ferran Davesa. 2012. El Impacto de la Cobertura Mediática de la corrupción en la Opinión Pública Española. Revista Española de Investigaciones Sociológicas 144: 97126.

Raunio Tapio and Simon Hix. (2000): Backbenchers learn to fight back: European integration and parliamentary government. West European Politics 23, 4: 142-168

Sampedro, Victor and Francisco Seoane Pérez. 2008. The 2008 Spanish General Elections: “Antagonistic Bipolarization” Geared by Presidential Debates, Partisanship, and Media Interest. The International Jounal of Press/Politics 13,3: 336-344

Semetko, Holli A. and Maria J. Canel. 1997. Agenda Senders versus Agenda-Setters:Television in Spain’s1996 Election Campaign. Political Communication 14: 459-479

Seymour-Ure, Colin. 1974. The Political Impact of Mass Media. London: Constable/Sage Seymour-Ure, Colin. 2003. Prime Ministers and the Media: Issues of Power and Control. Oxford: Blackwell 
Soroka, Stuart N. 2006. Good News and Bad News: Asymmetric Responses to Economic Information. The Journal of Politics 68, 2: 372-385

Stromback, Jesper. 2008. Four Phases of Mediatization: An Analysis of the Mediatization of Politics. The International Journal of Press/Politics 13, 3: 228-246

Stromback, Jesper and Daniela V. Dimitrova. 2011. Mediatization and Media Interventionism: A Comparative Analysis of Sweden and the United States The International Journal of Press/Politics 16, 1: 30-49

Stromback, Jesper and Peter Van Aelst.2013.Why Political Parties adapt to the Media: Exploring the Fourth Dimension of Mediatization. International Communication Gazette 75, 4: 341358.

Thesen, Gunnar. 2013. When Good News is Scarce and Bad News is Good: Government Responsibilities and Opposition Possibilities in Political Agenda Setting. European Journal of Political Research 52: 364-389

Tresch, Anke. 2009. Politicians in the Media: Determinants of Legislators' Presence and Prominence in Swiss Newspapers. The International Journal of Press/Politics 14, 1: 6790.

Villoria, Manuel. 2007. Informe Global 2007 Sobre la Corrupción en España. Madrid: Transparencia Internacional España.

Villoria, Manuel and Fernando Jiménez. 2012. La corrupción en España (2004-2010): datos, percepción y efectos, Revista Española de Investigaciones Sociológicas 138: 109-134

Walgrave, Stefaan and Peter Van Aelst. 2006. The Contingency of the Mass Media's Political Agenda Setting Power: Towards A Preliminary Theory. Journal of Communication 56: 88-109. 
Wolsfeld, Gadi and Tamir Sheafer. 2006. Competing Actors and the Construction of Political News: The Contest over Waves in Israel. Political Communication, 23, 3: 333-354. 


\section{TABLES AND FIGURES}

Table 1. Media coverage in El País and El Mundo, 1996-2011

\begin{tabular}{|c|c|c|c|c|c|c|c|}
\hline Newspaper & & $\begin{array}{c}\text { All } \\
\text { Stories }\end{array}$ & $\begin{array}{l}\% \text { of all } \\
\text { Front } \\
\text { Page }\end{array}$ & $\begin{array}{c}\text { PP } \\
\text { Governing }\end{array}$ & $\begin{array}{c}\text { PSOE } \\
\text { Governing }\end{array}$ & Elections & $\begin{array}{c}\text { Also } \\
\text { Mentioning } \\
\text { Government }\end{array}$ \\
\hline \multirow{8}{*}{ El Mundo } & Government & 6,723 & 13.2 & 2,823 & 3,900 & 276 & \\
\hline & PSOE & 5,841 & 11.5 & 2,330 & 3,511 & 645 & 1,261 \\
\hline & PP & 4,332 & 8.5 & 2,013 & 2,319 & 612 & 909 \\
\hline & IU & 491 & 1.0 & 346 & 145 & 86 & 105 \\
\hline & CIU & 604 & 1.2 & 343 & 261 & 64 & 109 \\
\hline & PNV & 935 & 1.8 & 711 & 224 & 82 & 162 \\
\hline & Other Basques & 452 & 0.9 & 206 & 246 & 60 & 22 \\
\hline & Other parties & 378 & 0.7 & 134 & 244 & 29 & 91 \\
\hline \multirow{8}{*}{ El País } & Government & 7,400 & 13.1 & 3,578 & 3,822 & 453 & 3,531 \\
\hline & PSOE & 3,657 & 6.5 & 1,698 & 1,959 & 618 & 2,078 \\
\hline & PP & 4,980 & 8.8 & 2,684 & 2,296 & 677 & 2,484 \\
\hline & IU & 519 & 0.9 & 310 & 209 & 93 & 206 \\
\hline & CIU & 688 & 1.2 & 439 & 249 & 81 & 298 \\
\hline & PNV & 931 & 1.6 & 644 & 287 & 110 & 371 \\
\hline & Other Basques & 321 & 0.6 & 138 & 183 & 53 & 98 \\
\hline & Other parties & 229 & 0.4 & 132 & 97 & 24 & 13 \\
\hline
\end{tabular}


Table 2. Operationalization of Dependent and Independent Variables

\begin{tabular}{ll}
\hline Dependent Variable & Description \\
\hline Media coverage & $\begin{array}{l}\text { The analysis covers six political parties that at some point } \\
\text { are governing or giving support to the government: Partido } \\
\text { Popular (PP), Partido Socialista Obrero Español (PSOE), } \\
\text { Izquierda Unida (IU), Convergència I Unió (CIU), Partido } \\
\text { Nacionalista Vasco (PNV), Esquerra Republica de } \\
\text { Catalunya (ERC). } \\
\text { Therefore we present six models, one for each party. In } \\
\text { each case, the dependent variable is simply the percentage } \\
\text { of all front page stories that mention that party. Analysis is } \\
\text { monthly. }\end{array}$ \\
\hline Independent Variables & $\begin{array}{l}\text { Description } \\
\text { 1. Governing or giving support } \\
\text { to the government } \\
\text { support to the government; } 0 \text { otherwise }\end{array}$ \\
2. Elections & $\begin{array}{l}\text { 1 during the two months before elections; 0 otherwise. } \\
\text { 3. Satisfaction with the } \\
\text { economy }\end{array}$ \\
& $\begin{array}{l}\text { The percentage of Spanish citizens that consider the } \\
\text { economic situation in Spain to be good or very good. This is } \\
\text { monthly data from the Barometers elaborated every month } \\
\text { by the Centro de Investigaciones Sociológicas. The } \\
\text { information is directly available at www.cis.es. }\end{array}$ \\
\hline Period & $\begin{array}{l}\text { 1996 to 2011. The analysis goes from January 1996 to } \\
\text { November 2011, right after the general elections won by the } \\
\text { Partido Popular, lead by Mariano Rajoy. }\end{array}$ \\
\hline Total number of months & 191 \\
\hline
\end{tabular}


Table 3. Determinants of Media Coverage for Spanish Political Parties

\begin{tabular}{|c|c|c|c|c|c|c|c|}
\hline & & $\mathrm{PP}$ & PSOE & IU & CIU & PNV & ERC \\
\hline \multirow[t]{8}{*}{ El Pais } & Governing & $2.043 * *$ & $1.526 * *$ & -.094 & $.678 * *$ & -.147 & $8.631^{* * * *}$ \\
\hline & Elections & $6.631 * * *$ & $3.214 * * *$ & $.868 * *$ & .181 & -.600 & -2.772 \\
\hline & Economy & $-.093^{* *}$ & $-.047^{*}$ & $.016^{* *}$ & -.009 & $.026^{* * *}$ & $.205^{* * *}$ \\
\hline & Constant & $16.393 * * *$ & $8.085^{* * *}$ & .222 & $1.713 * * *$ & .032 & $-9.097 * *$ \\
\hline & $\mathrm{F}$ & 10.211 & 16.290 & 5.424 & 3.094 & 8.152 & 13.721 \\
\hline & $\mathrm{R}^{2}$ & .127 & .207 & .065 & .032 & .101 & .167 \\
\hline & Governing & .393 & $3.568 * * *$ & $-912 * * *$ & $.722 * *$ & $.808^{* *}$ & $1.231^{* * *}$ \\
\hline & Elections & $4.944 * * *$ & $4.718 * * *$ & $1.884 * * *$ & .871 & .414 & .183 \\
\hline \multirow[t]{4}{*}{ El Mundo } & Economy & $-.139 * * *$ & $-159 * * *$ & .002 & $-.024 *$ & $.051^{* * *}$ & $.031 * * *$ \\
\hline & Constant & $14.000 * * *$ & $17.371 * * *$ & $1.342 * *$ & $2.007 * * *$ & -.568 & -1.451 \\
\hline & $\mathrm{F}$ & 20.287 & 44.677 & 21.534 & 3.555 & 18.493 & 35.100 \\
\hline & $\mathrm{R}^{2}$ & .235 & .408 & .245 & .039 & .216 & .350 \\
\hline
\end{tabular}

Note: Entries are OLS regression coefficients; the dependent variable is the percentage of front page stories per month in which the indicated political party appears. "Governing" is coded 1 when the party in question is either in the government, or supporting the government in Parliament. "Elections" = 1 during the two months preceding a general election. "Economy"= percent of respondents reporting that the state of the economy is good or very good. $\mathrm{N}=191$ months from 1996 through 2011. PP: Partido Popular; PSOE: Partido Socialista Obrero Español, IU: Izquierda Unida; CIU: Convergència i Unió, PNV: Partido Nacionalista Vasco, ERC: Esquerra Republicana de Catalunya. 
Figure 1. Attention during routine and election periods.

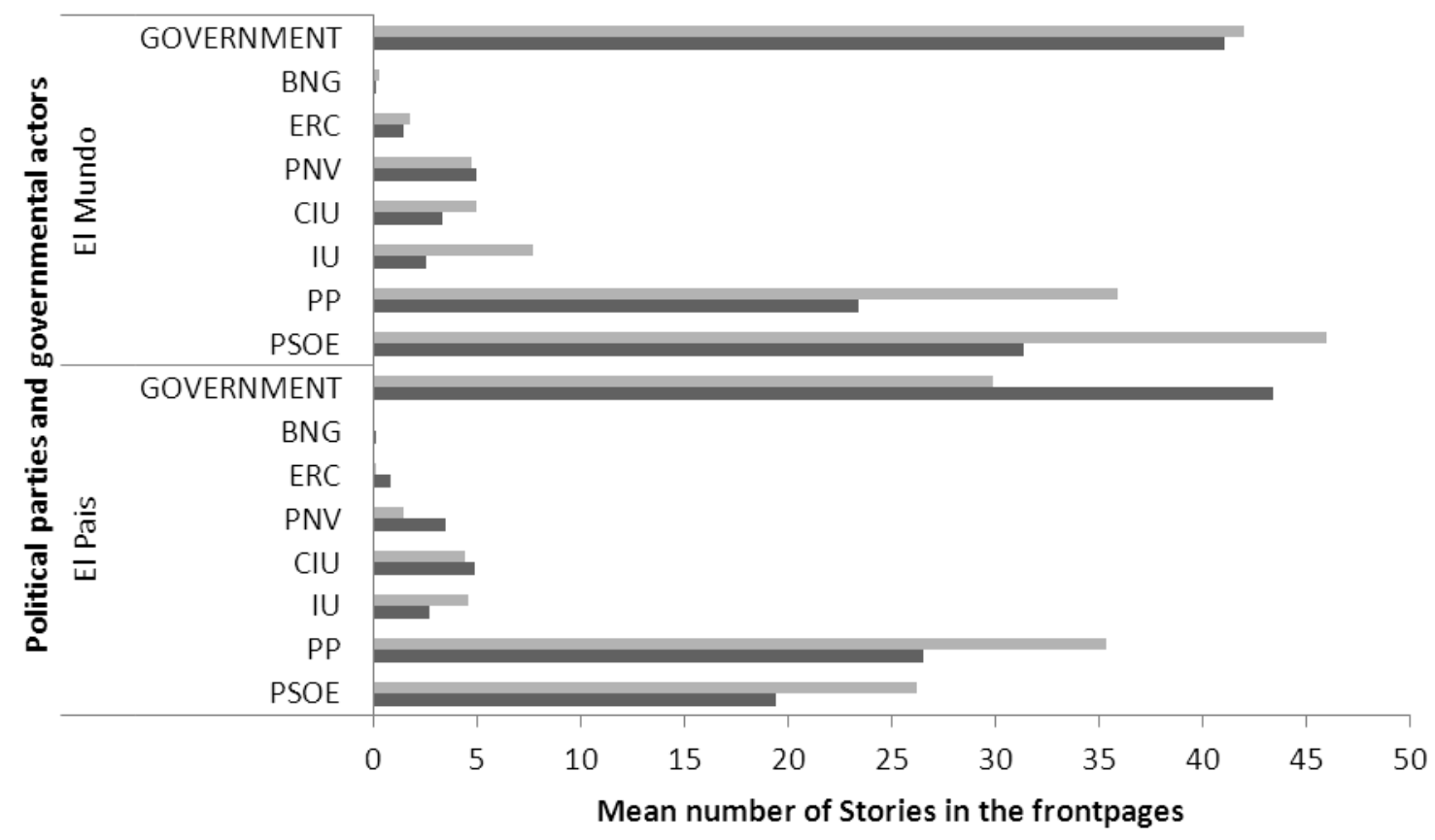

Elections $\square$ Routine Period 
Figure 2A. Attention to political parties during political campaigns, El País

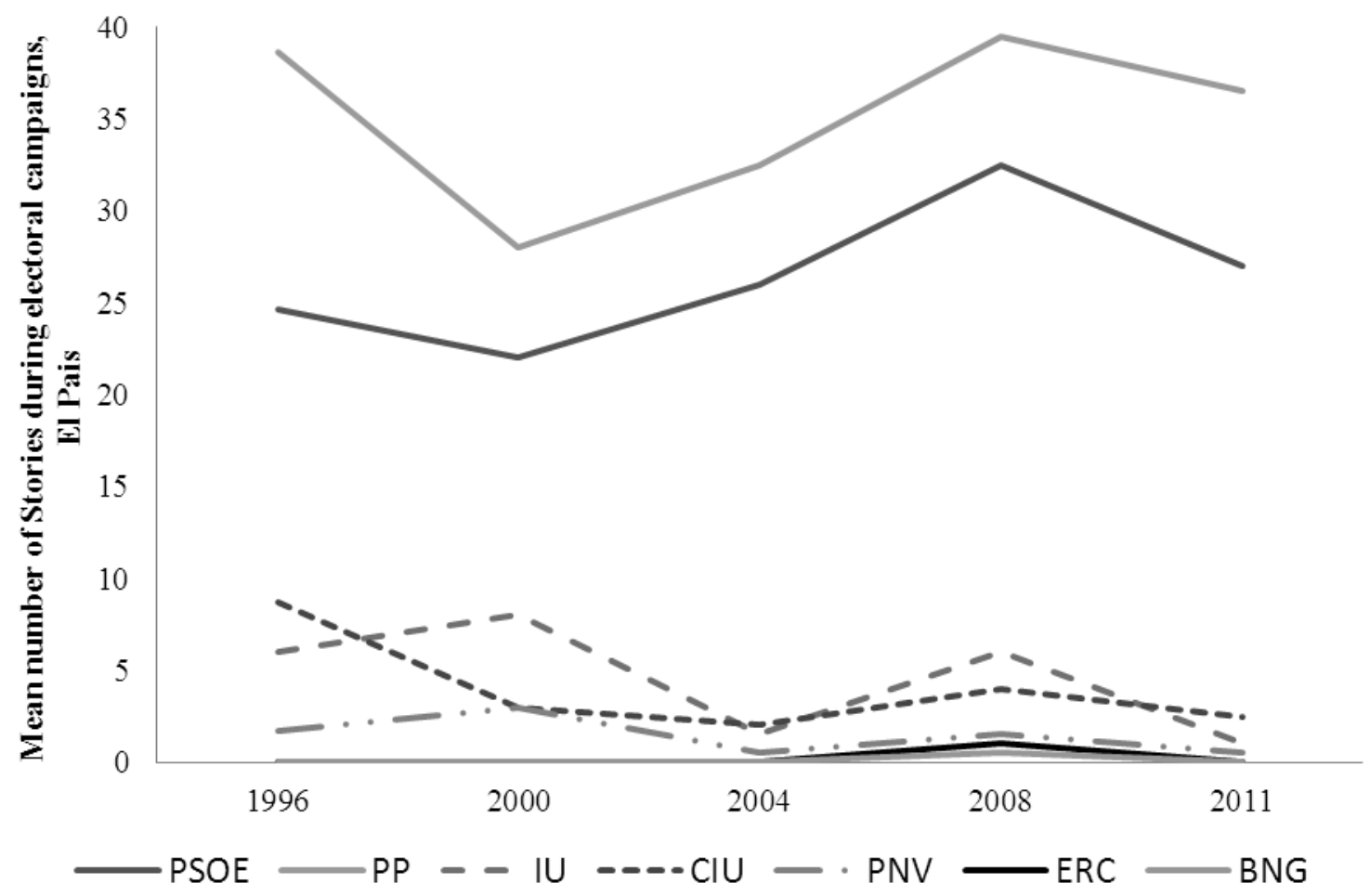

Figure 2B. Attention to Political parties during electoral campaigns, El Mundo

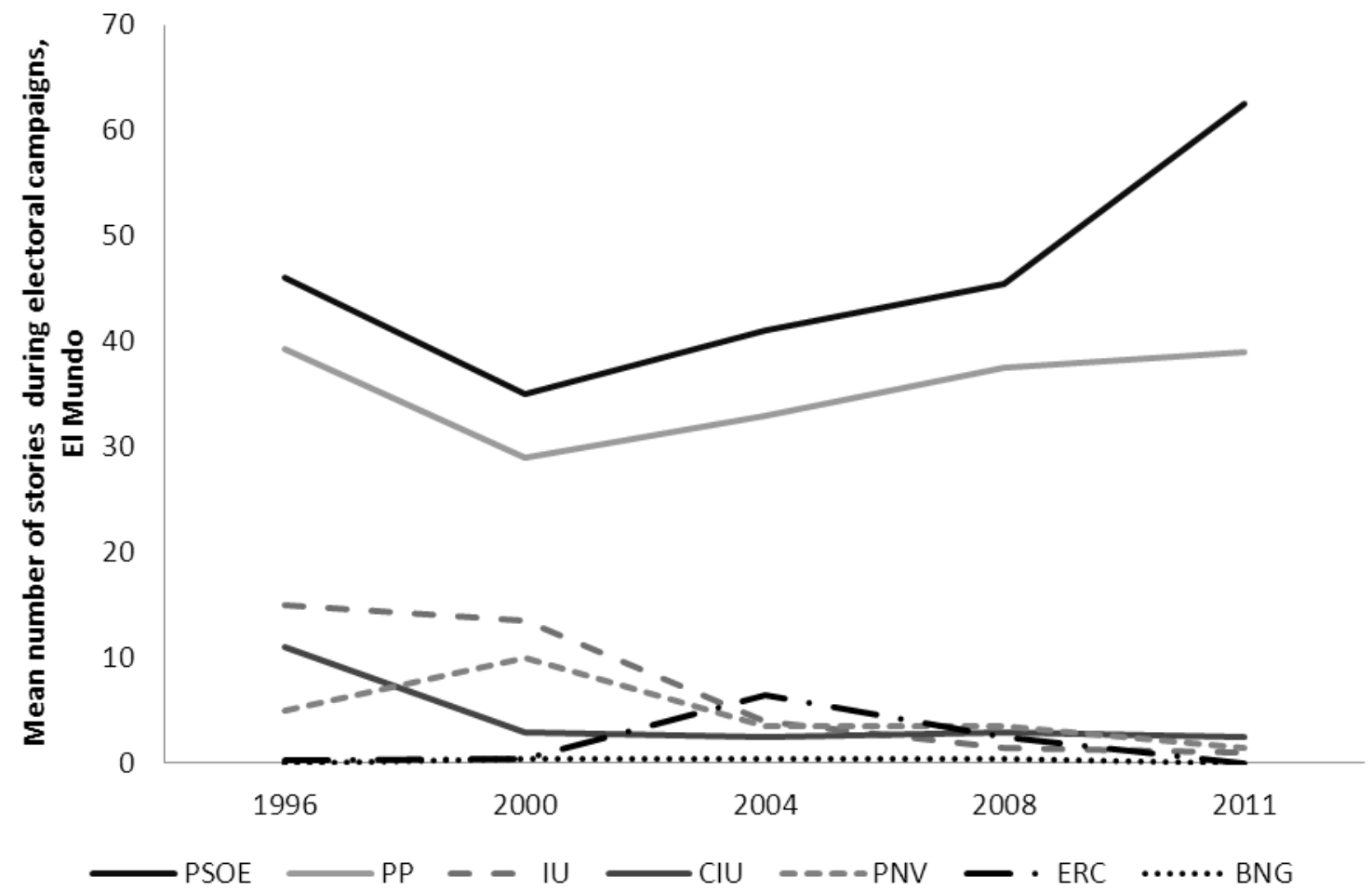


Figure 3. Government and political party coverage by topic area.

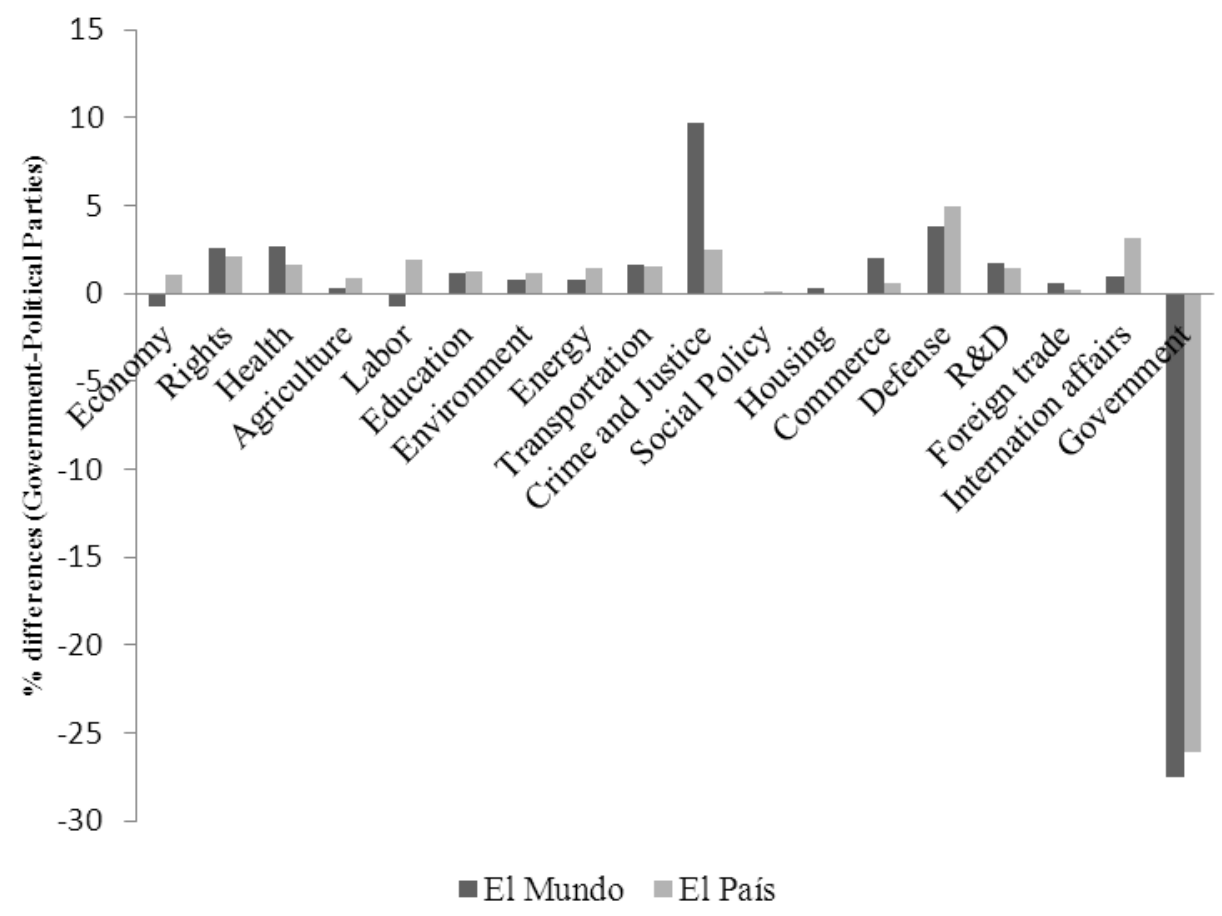


Figure 4. Agenda fragmentation across issues by actor, 1996-2011 A. El País

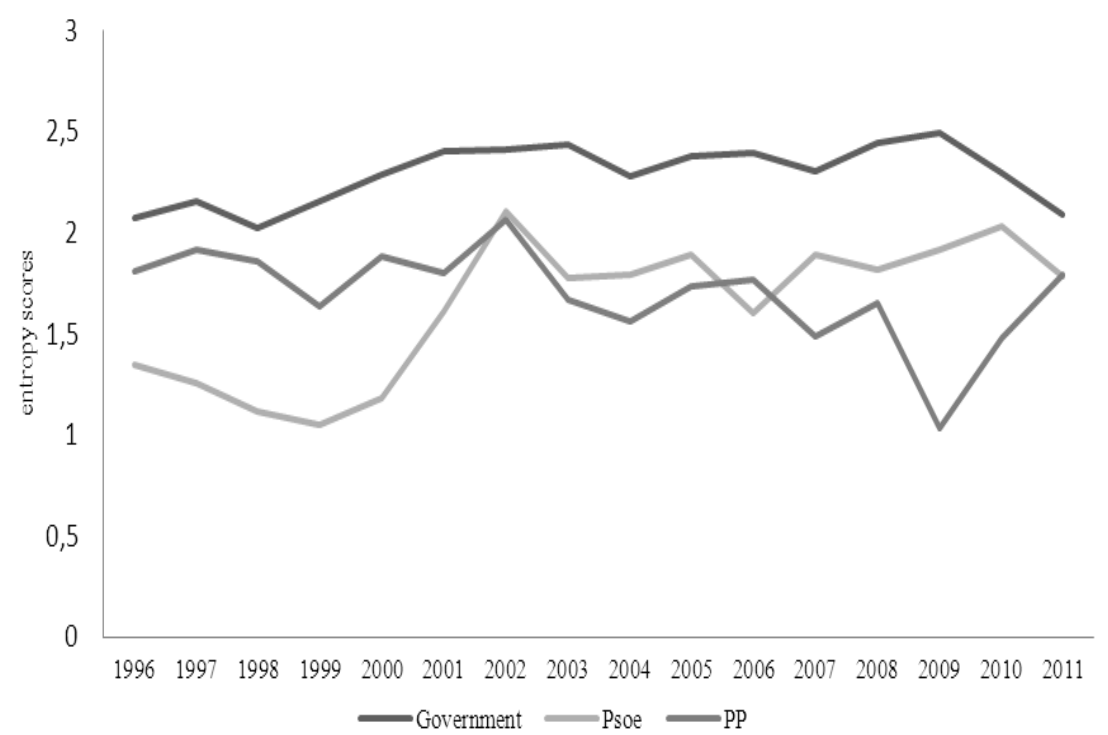

B. El Mundo

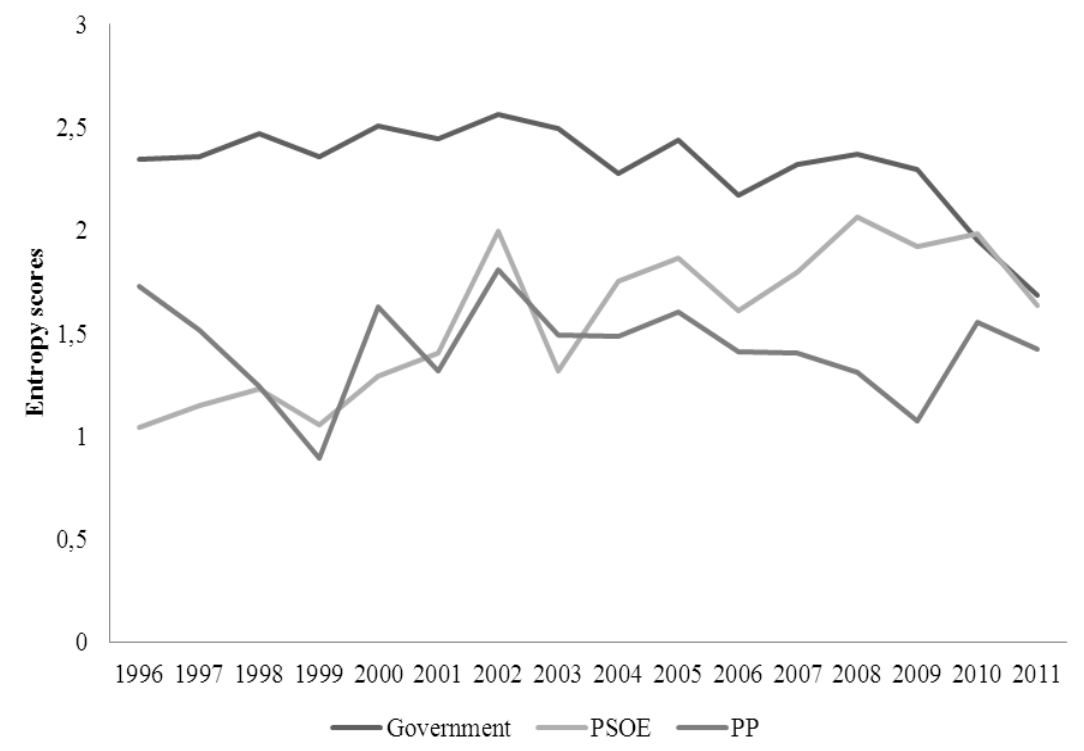


Figure 5. Mentions by paper: corruption

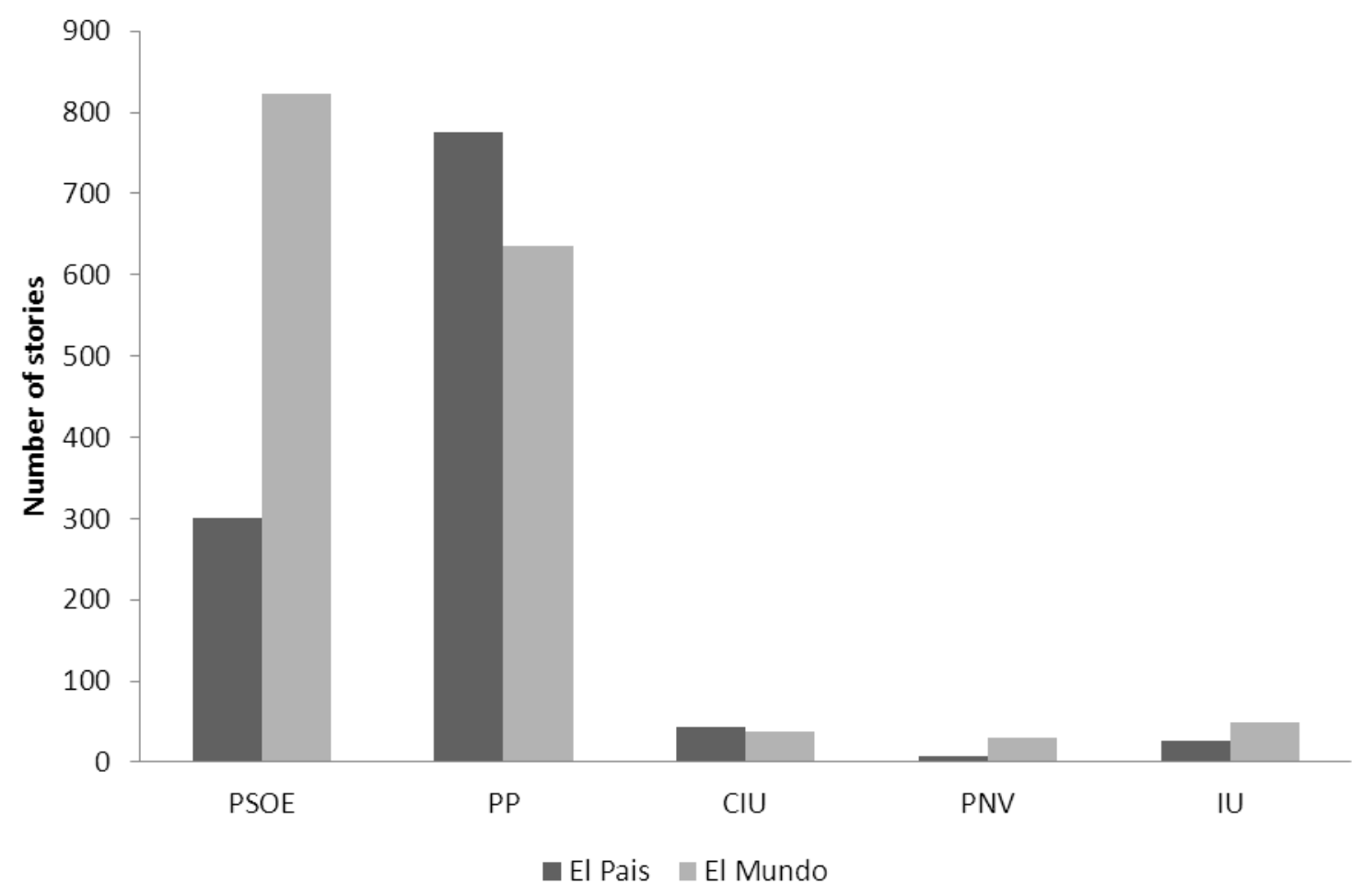


Figure 6. Partisan targeting during the PSOE Government

A. El País

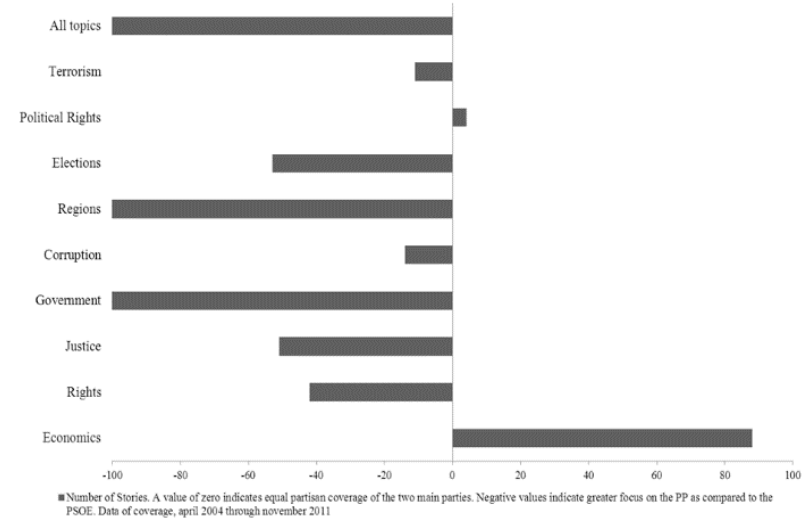

B. El Mundo

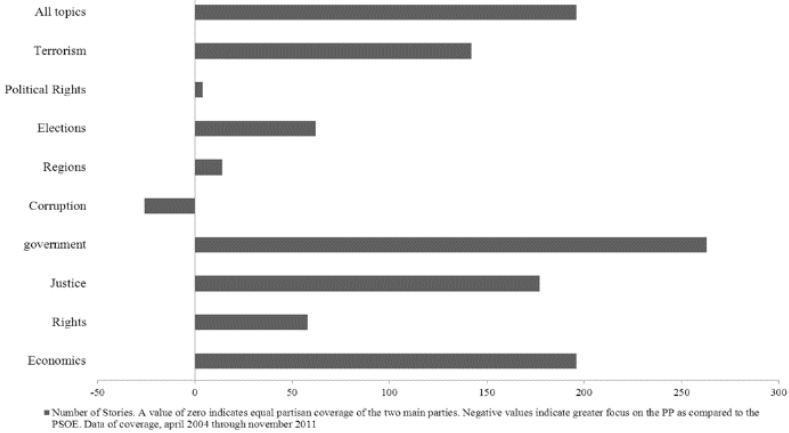


Figure 7. Partisan targeting during the PP government

A. El País

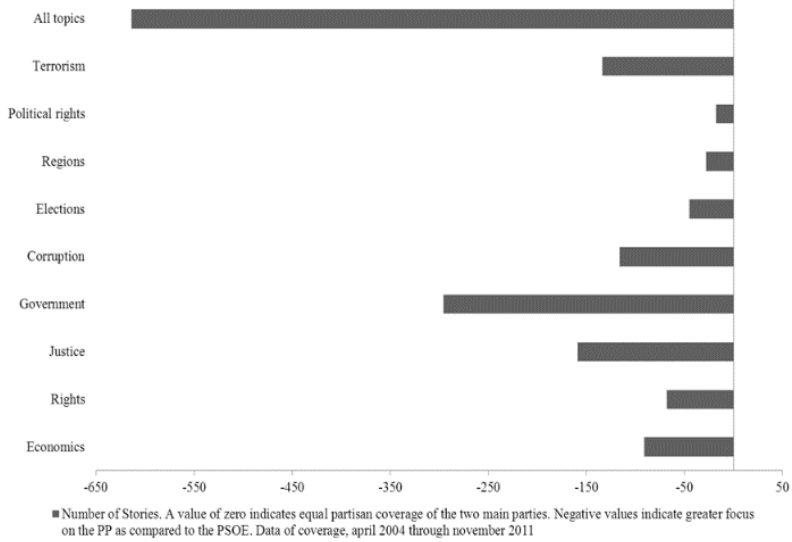

B. El Mundo

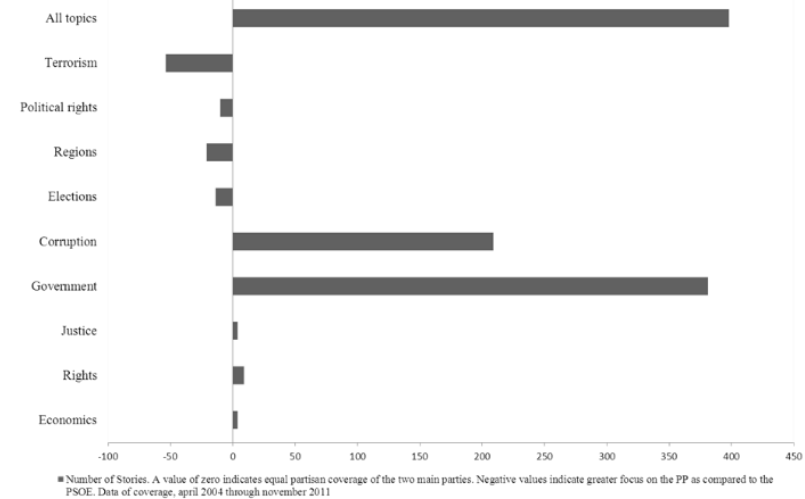




\begin{tabular}{ll} 
Appendix A. List of Major Topic Codes in the Spanish Agendas Project. \\
\hline Topic & Description \\
\hline 1 & Economy \\
2 & Rights \\
3 & Health \\
4 & Agriculture \\
5 & Labor \\
6 & Education \\
7 & Environment \\
8 & Energy \\
10 & Transport \\
12 & Justice \\
13 & Social \\
14 & Housing \\
15 & Business \\
16 & Defense \\
17 & Science \\
18 & Foreign Trade \\
19 & International \\
20 & Government \\
21 & Public Lands \\
23 & Culture \\
27 & Weather \\
29 & Sports \\
30 & Death Notices \\
\hline
\end{tabular}




\section{Endnotes}

${ }^{1}$ The Grupo Zeta publishes one of the most read sports newspapers in Spain (Sport) and El Periodico de Catalunya. There is also a Periódico in Extremadura and Aragón. Together they are the third most read quality paper after El País and El Mundo in Spain. Still, most of its readers are located in Catalonia, and voters of Catalan political parties (see any of the annual reports of the AIMC and the survey number 2920 of the Centro de Investigaciones Sociológicas).

${ }^{2}$ In 2011, most of the 68 newspapers in Spain were local newspapers with low circulation levels and low quality profiles. Nationwide newspapers are a few, but account for most of the readers_El País and El Mundo account for more than 25\% of readers nationwide-and dominate the political discourse (Berges 2010, Bustamante 2002, de Mateo 2010, McChesney 2003). Finally, in some regions like Catalonia, Galicia or The Basque Country, regional newspapers-like La Vanguardia, la Voz de Galicia or El Diario Vasco-account for an important share of the readers, and have an important impact on the political debate.

${ }^{3}$ Data on media parallelism is only available in terms of readership. The Centro de Investigaciones Sociológicas (CIS) introduced a specific question in several polls in order to capture this link between ideology, political parties and newspapers readers. Here, we provide data from two different surveys: studio no 2920/0 Post-electoral Elecciones Generales 2011, (question 25a); and studio $\mathrm{n}^{\mathrm{o}} 2798$ Barómetro de abril 2009, (question 13c). In both questions respondants were asked about which newspaper they read to get information about politics. Here, the ideological scale goes from 1 (far left) to 10 (far right).

${ }^{4}$ Besides from academic research (eg. Sampedro 2009), institutions like Freedom House or Journalist without barriers provide data about the erosion of media freedom in Spain. 
${ }^{5}$ The Ley Orgánica 6/2002, de 27 de junio, de Partidos Políticos) also outlawed the Communist Party of Spain (Reconstituted) considering that along with GRAPO terrorist was a single structure. The law was passed with the agreement of all political parties but the far left (IU-ICV), left regional parties including the ERC and BNG, and all Basque parties.

${ }^{6}$ The formula is: Entropy $=(\mathrm{p}(\mathrm{x}) * \log (\mathrm{p}(\mathrm{x}))$, where $\mathrm{p}(\mathrm{x})$ represents the proportion of stories on an issue (there are 23 issues in the Spanish agendas project list of topics; see Appendix A). This was originally developed in the field of thermodynamics to measure the diffusion of heat, but it has been later adapted to political science and social sciences in general to analyze scope (see Baumgartner et al. 2008, Boydstun 2013). Economists use similar measures to analyze the concentration of firms in an industry: High entropy would refer to great competition, whereas low entropy would mean one firm monopolizes or dominates an industry. ${ }^{7}$ Our focus on front-page news stories may limit our ability to speak generally about small parties in the media. It is possible that such parties are more often covered in the inside pages of the nation's leading newspapers. Still, the front pages are important indicators of public discussion and while it would be of great interest to know if the results might differ when including inside-page articles, the degree of advantage to the larger parties on the front pages is clearly an important element of the Spanish media system, and likely in others as well. 